\title{
Potensi Daun Tempuyung (Sochus arvensis L) Sebagai Antihiperurisemia pada Mencit Putih Jantan
}

\author{
Nur Fahma Laili ${ }^{1 *}$, Lisa Savitri ${ }^{2}$ \\ ${ }^{1}$ Program Studi Farmasi, Universitas Kadiri, Jalan Selomangleng No. 1 Kota Kediri \\ ${ }^{2}$ Program Studi Teknologi Laboratorium Medis, Universitas Kadiri, Jalan Selomangleng No. 1 Kota Kediri \\ *Correspondence email: nurfahmalaili@unik-kediri.ac.id
}

\begin{abstract}
Abstrak. Kondisi hiperurisemia terjadi akibat sintesis yang berlebihan dari kegagalan ginjal dalam mengeliminasi asam urat. Hiperurisemia apabila dibiarkan terus-menerus akan memicu kelainan kronis seperti kelainan ginjal, kardiovaskuler dan gout. Salah satu upaya alternatif pengobatan secara tradisional melalui tanaman herbal. Daun tempuyung diduga memiliki potensi dalam menurunkan kadar asam urat . Penelitian ini bertujuan untuk mengetahui apakah daun tempuyung memiliki potensi dalam penurunan kadar asam urat. Rancangan metode penelitian dengan desain pre-post test with control group menggunakan 30 hewan uji mencit jantan galur Balb/c. sebelum mencit diberikan perlakuan larutan uji mencit dibuat kondisi hiperurisemia dengan pemberian larutan uji potasium oxsonat. Hasil penelitian menunjukkan bahwa larutan ekstrak etanol $70 \%$ dapat berpotensi menurunkan kadar asam urat dengan dosis $12,8 \mathrm{mg} / 20 \mathrm{BB}$ dapat memberikan penurunan 64,267\%. Senyawa aktif yang diduga memiliki aktivitas dalam penuruna kadar asam urat yaitu senyawa flavonoid (luteolin dan apigenin) yang bekerja sebagai inhibitor enzim xanthin oksidase sehingga pembentukan asam urat dapat terhambat.
\end{abstract}

Kata kunci: Asam urat; flavonoid; hiperurisemia; Sonchus arvensis

Abstract. Hyperuricemia condition occurs due to the excessive synthesis of kidney failure to eliminate uric acid. Hyperuricemia if allowed to continue will lead to chronic disorders such as kidney, cardiovascular, and gout disorders. One of the traditional alternative medicine efforts is through herbal plants. Tempuyung leaves are thought to have the potential to reduce uric acid levels. This study aims to determine whether tempuyung leaves have the potential to reduce uric acid levels. The design of the research method was the pre-post test design with the control group using 30 test animals of male Balb/c mice. Before the mice were given the treatment of the test solution, the hyperuricemia condition was made by administering the potassium oxsonate test solution. The results showed that 70\% ethanol extract solution had the potential to reduce uric acid levels at a dose of $12.8 \mathrm{mg} /$ $20 \mathrm{BW}$ which could provide a decrease of $64.267 \%$. The active compounds that are thought to have activity in reducing uric acid levels are flavonoids (luteolin and apigenin) which work as inhibitors of the xanthine oxidase enzyme so that the formation of uric acid can be inhibited.

Keywords: Uric acid; flavonoids; hyperuricemia; Sonchus arvensis

\section{PENDAHULUAN}

Kondisi hiperurisemia adalah kondisi dimana pada kadar asam urat darah terjadi peningkatan yaitu kadar asam urat serum lebih dari $7 \mathrm{mg} / \mathrm{dl}$ pada laki-laki dan lebih dari $6 \mathrm{mg} / \mathrm{dl}$ pada wanita (Nasrul E dan sofitri., 2012). Peningkatan kadar tersebut akan menyebabkan kondisi yang lebih parah pada gout arthritis dan penurunan fungsi ginjal (Boleu et al., 2018). Faktor penyebab terjadinya kondisi hiperurisemia adalah peningkatan produksi asam urat atau penurunan ekskresi disebabkan diet tinggi purin melalui mekanisme pemecahan asam nukleat yang diubah menjadi asam urat yang merupakan produk akhir metabolisme purin. Purin merupakan senyawa basa organik yang termasuk dalam kelompok asam amino menyusun asam nukleat. Contoh makanan yang mengandung kadar purin tinggi adalah jeroan, daging sapi, kdaging kambing, sea food, kacangkacangan, bayam, jamur, makanan kaleng dll) (Dianati Nur A, 2015).

Data Word Health Organization prevalensi tertinggi gout arthritis didunia sebanyak $34,2 \%$, kejadian ini banyak terjadi di Negara berkembang termasuk di
Negara Indonesia (WHO, 2017). Prevalensi penyakit asam urat meningkatkan dibuktikan dengan data hasil Riskesdas 2018 menyebutkan bahwa prevalensi tertinggi berdasarkan diagnosis dokter di Indonesia 24,7\% . Proporsi tingkat kejadian penyakit sendi tertinggi terjadi pada lansia usia $>75$ tahun $(54,8 \%)$ dengan jumlah kasus wanita $(8,46 \%)$ lebih banyak dibanding pria (6,13\%) (Riskesdas, 2018).

Indonesia banyak dengan keanekaragaman bahan alam yang secara empiris dapat digunakan untuk menurunkan kadar asam urat salah satunya adalah Daun Tempuyung (kristiani et al., 2013). Daun tempuyung memiliki kandungan senyawa ion-ion mineral seperti kalium, silika, natrium, magnesium, dan beberapa flavonoid (kaempferol, luteolin-7-Oglukosida, dan apigenin-7-O-glukosida), kumarin (skepoletin), taraksterol, inositol, asam fenolat (sinamat, kumarat, dan vanilat) , beberapa penelitian menyebutkan bahwa kandungan senyawa aktif yang dapat berpotensi dalam penurunan kadar asam urat adalah senyawa flavonoid yang bekerja dengan menghambat aktivitas enzim xantin oksidase dengan cara mengkonversi xantin menjadi 
asam urat (Cendrianti Ferani et al., 2014; Adelia Anisa, 2020)

\section{METODE}

\section{Bahan dan alat Penelitian}

Bahan yang digunakan dalam penelitian adalah daun tempuyung, pelarut etanol $70 \%$, aquadest, kalium oksonat, allupurinol, kit reagen (DHBSA).

Alat yang digunakan pada penelitian ini adalah neraca analitik digital, oven, blender, mess, seperangkat alat gelas, sonde, spuit, jarum suntik, pipa kapiler hematokrit, microtip, sentrifuge, vial, penjepit kayu, densitometer, lampu UV.

\section{Uji Hiperurisemia terhadap mencit putih jantan}

Penelitian ini merupakan jenis penelitian experimental dengan desain pre-post test with control group dengan menggunkan hewan uji mencit putih jantan dengan rata-rata berat 20-30 gram dan berusia 2-3 bulan sebagai obyek penelitian. Hewan uji dibagi menjadi 6 kelompok yang masing-masing kelompok terdiri dari 5 mencit uji. Hewan uji dipuasakan dan diaptasikan dengan lingkungannya selama 2 minggu.

$\mathrm{K}(-)$ : Mencit uji diberikan aquadest $0,5 \mathrm{ml}$

$\mathrm{K}(+)$ : Mencit uji diberikan Allupurinol dosis $10 \mathrm{mg} / \mathrm{kgBB}$

Mencit uji dibuat hiperurisemia dengan pemberian Potasium oxsonat dosis $300 \mathrm{mg} / \mathrm{kgBB}$

$\mathrm{K}(+$ hiperurisemia: Mencit uji diberikan Allupurinol dosis $10 \mathrm{mg} / \mathrm{kgBB}$

P1: Setelah 1 jam mencit hiperurisemia diberikan larutan Ekstrak daun tempuyung dosis 1 (7,68 mg/20g BB)

P2: Setelah 1 jam mencit hiperurisemia diberikan larutan Ekstrak daun tempuyung dosis $2(10,24 \mathrm{mg} / 20 \mathrm{~g} \mathrm{BB})$

P3: Setelah 1 jam mencit hiperurisemia diberikan larutan Ekstrak daun tempuyung dosis $3(12,8 \mathrm{mg} / 20 \mathrm{~g} \mathrm{BB})$

Pengamatan dilakukan Setelah 2 jam mencit uji diberikan perlakuan, kemudian mencit dibedah melalui jantung untuk pengambilan darah. Kadar asam urat ditetapkan berdasarkan reaksi enzimatik menggunakan reagen uric acid $F S^{*} T B H B A$, dengan cara $20 \mu \mathrm{L}$ serum ditambah dengan $1000 \mu \mathrm{L}$ reagen 1 . Kocok dan diinkubasi selama 5 menit, kemudian tambah dengan reagen $2250 \mu \mathrm{L}$. Kocok sampel dan diinkubasi selama 10 menit pada suhu $37^{\circ} \mathrm{C}$. Selanjutnya larutan sampel, standart dan blangko dibaca absorbansinya dengan menggunakan spektrofotometer StartDust FC*15 pada panjang gelombang $546 \mathrm{~nm}$.

\section{Analisis Data}

Data dianalisis diolah dengan menggunakan SPSS dengan melakukan uji normalitas data (Shapiro-Wilk) dan uji homogenitas (Lavene's-test). Kemudian melakukan uji ANOVA one way untuk melihat signifikansi pengaruh perbedaan rata-rata dari dua/lebih kelompok perlakuan dinyatakan signifikan jika p-value <
0,05 dan dilanjutkan dengan uji post hoct tukey HSD Test untuk melihat perbedaan yang paling signifikan antar kelompok perlakuan (Ghozali, 2011)

\section{HASIL DAN PEMBAHASAN}

Gambar 1 menunjukkan rerata antar kelompok kontrol dan kelompok perlakuan dengan kadar asam urat darah pada mencit putih jantan setelah pemberian potasium oxsonat. Pada kelompok kontrol positif diberikan larutan uji Potasium oxsonat diberikan pada hewan uji sebagai agen hiperurisemia yang bekerja menghambat enzim uricase di hati, dimana pada hewan uji merupakan inhibitor uricase yang kompetitif untuk meningkatkan kadar asam urat dengan jalan mencegah perubahan asam urat menjadi allantoin. Dimana allantoin bersifat larut dalam air dan dapat di ekskresi lewat urin sehingga asam urat dengan mudah dikeluarkan (Laksmitawati et al., 2017). Asam urat hasil degradasi nukelotida purin pada sel yang merupakan produk akhir dari katabolisme purin. Kondisi hiperurisemia terjadi apabila keadaan kelebihan kadar asam urat darah akibat pemberian potasium oxsonat. setelah 1 jam pemberian potasium oksonat diberikan larutan uji allupurinol, larutan extrak tempuyung dengan berbagai dosis yaitu 7,68 mg, 10,24 mg, 12,8 mg. hasil tabel 1 menunjukkan persen penurunan kadar asam urat paling besar yaitu pada kelompok kontrol positif dengan pemberian allupurinol $10 \mathrm{mg} / \mathrm{kgBB}$. Allupurinol sebagai inhibitor dari xantin oksidase sehingga menghambat konversi xantin dan hipoxantin menjadi asam urat. Sehingga dapat menurunkan kadar asam urat pada mencit uji.

Pada kelompok uji ekstrak tempuyung dengan variasi 3 dosis menunjukkan penurunan terbesar pada kelompok dosis $12,8 \mathrm{mg}$ dengan persentase $64,267 \%$. Pada daun tempuyung mengandung golongan senyawa flavonoid yaitu 7,4-dihidroksi flavon, sesquiterpene dari golongan terpenoid, turunan asam kuinat dan sesquiterpene, minyak atsiri, alkaloid, asam fenolat (Putra et al., 2013).

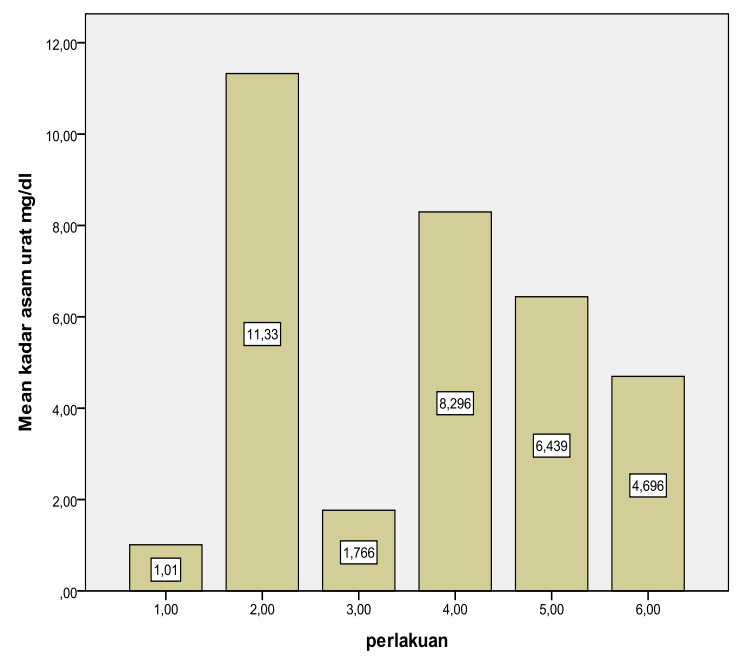

Gambar 1. rerata antar kelompok perlakuan dengan kadar asam urat darah pada mencit 
Tabel 1. Tabel penurunan kadar asam urat

\begin{tabular}{clccc}
\hline Sampel & mencit & Absorbansi & $\begin{array}{c}\text { Kadar Asam } \\
\text { urat (mg/d) }\end{array}$ & $\begin{array}{c}\text { Persen penurunan } \\
\text { kadar asam urat }\end{array}$ \\
\hline $\mathrm{K}(+)$ & 1 & 0,079 & 1,789 & $92,665 \%$ \\
& 2 & 0,066 & 1,494 & \\
& 3 & 0,082 & 11,857 & \\
& 4 & 0,095 & 2,151 & \\
& 5 & 0,062 & 1,540 & $29,367 \%$ \\
$\mathrm{P} 1$ & 1 & 0,362 & 8,196 & \\
& 2 & 0,377 & 8,536 & \\
& 3 & 0,383 & 8,649 & \\
& 4 & 0,353 & 7,992 & \\
$\mathrm{P} 2$ & 5 & 0,358 & 8,106 & \\
& 1 & 0,271 & 6,136 & \\
& 2 & 0,296 & 6,091 & \\
& 3 & 0,312 & 7,064 & \\
& 4 & 0,294 & 6,657 & \\
P3 & 5 & 0,276 & 6,249 & \\
& 1 & 0,202 & 4,574 & \\
& 2 & 0,212 & 4,800 & \\
& 2 & 0,236 & 5,343 & \\
& 4 & 0,198 & 4,483 & \\
\hline
\end{tabular}

Pada daun tempuyung kandungan senyawa yang paling tinggi adalah flavonoid yaitu merupakan senyawa flavon yang bersifat antioksidan yang bekerja dengan menghambat kerja enzim xanthin oksidase dan superoksida sehingga terhambat pembentukan asam urat. Senyawa flavonoid yang diduga dalam menurunkan kadar asam urat yaitu flavonoid apigenin 7-o-glukosida. Pada penelitian cendriantri Ferani et al., 2014 bahwa ekstrak etil asetat dan etanol $70 \%$ daun tempuyung dosis $300 \mathrm{mg} / \mathrm{kg}$ BB memiliki aktivitas antihiperurisemia yang sebanding pada mencit hiperurisemia. Penelitian Nagao et al (2014), menyatakan bahwa kandungan berkhasiat pada ekstrak tempuyung adalah senyawa flavonoid luteolin yang memiliki nilai hambat xanthin oksidase nilai hambat IC50 sebesar $0,96 \mu \mathrm{M}$ dan $0,55 \mu \mathrm{M}$ dan senyawa flavonoid apigenin memiliki IC sebesar 29,1 $\mu \mathrm{M}$ dan $0,70 \mu \mathrm{M}$. Kandungan senyawa flavonoid dapat menghambat enzim xanthin oksidase disebabkan karena adanya gugus hidroksil pada ataom C-5 atau C-7 dan adanya ikatan rangkap antara $\mathrm{C}-2$ dan $\mathrm{C}-3$ sehingga terjadi reaksi adisi karena berinteraksi dengan enzim pada gugus samping (Adelia Anisa., 2020).

\section{SIMPULAN}

Ekstrak etanol $70 \%$ daun tempuyung memiliki potensi dalam penurunan kadar asam urat pada mencit jantan yang diinduksi potasium oksonat dan pada dosis ekstrak tempuyung $12,8 \mathrm{mg} / 20 \mathrm{BB}$ dapat memberikan penurunan sebesar $64,267 \%$

\section{DAFTAR PUSTAKA}

Adelia Anisa. (2020). Studi literatur pengaruh ekstrak daun tempuyung (Sonchus Arvensis) terhadap aktivitas xantin oksidase untuk Pengobatan hiperurisemia, Jurnal Ilmu Kedokteran Dan Kesehatan, Vol.7 (4). 604-612.
Boleu Fiktor I , Jubhar C. Mangimbulude ,Karwur Ferry F, (2018). Hyperurisemia dan hubungan antara asam urat darah dengan gula darah sewaktu dan imt pada komunitas etnik asli di halmahera utara, Jurnal Ilmu Kesehatan Masyarakat, 9(2):96-106.

Cendrianti Ferani, Muslichah Siti, Ulfa Evi Umayah. (2014). Uji Aktivitas Antihiperurisemia Ekstrak nHeksana, Etil Asetat, dan Etanol 70\% Daun Tempuyung (Sonchus arvensis L.) pada Mencit Jantan Hiperurisemia, e-Jurnal Pustaka Kesehatan, vol. 2 (2). 205-210.

Dianati Nur Amalia. (2015). Gout and Hyperuricemia, J Majority, Vol 4(3). 82-89

Imam, Ghozali. (2011). "Aplikasi Analisis Multivariate dengan Program IBM SPSS 19”. Edisi 5. Semarang: Badan Penerbit Universitas Dipenegoro.

laksmitawati Dian Ratih, Nurhidayati liliek, Arifin mochamad futuchul , Bahtiar Bagus. (2017). Optimasi Konsentrasi Ekstrak dan Bahan Pengikat Polivinil Pirolidon pada Granul Ekstrak Daun Sirih Merah (Piper crocatum Ruiz \& Pav) sebagai Antihiperurisemia, jurnal ilmu kefarmasian indonesia, Vol 15 (2): 216-222.

Nagao Akihiko, Seki Michiko \& Kobayashi Hidetaka. (1999) Inhibition of Xanthine Oxidase by Flavonoids, Bioscience, Biotechnology, and Biochemistry, 63:10, 1787-1790.

Nasrul Ellyza, Sofitri. (2012). Hiperurisemia pada Pra Diabetes, Jurnal Kesehatan Andalas. Vol 1(2). 8291.

Putra a buyung Rukmantara Susena, Kusrini a Dewi , Fachriyah a Enny. (2013) Isolasi Senyawa Antioksidan dari Fraksi Etil Asetat Daun Tempuyung (Sonchus arvensis L). Jurnal Kimia Sains dan Aplikasi 16 (3): 69 - 72.

Riset Kesehatan Dasar (Riskesdas) (2018). Badan Penelitian dan Pengembangan Kesehatan Kementerian RI tahun 2018.

World Health Organization (WHO). (2017). WHO Methods and data sources global burden of diasese estimates 2000-2015. 